\title{
EFFECTS OF SINGLE ACUPUNCTURE POINT STIMULATION ON MECHANICAL EXPERIMENTAL PAIN
}

\author{
Gligor Mastilović ${ }^{1}$, Brankica Dimitrijević ${ }^{1}$, Ljubica Konstantinoviće
}

${ }^{1}$ Faculty of Medicine, University of Belgrade, Serbia
${ }^{2}$ Mentor: Rehabilitation Clinic "Dr Miroslav Zotović" "Dr Miroslav Zotović"

Sažetak

Uvod: U terapiji bola u zapadnim zemljama akupunktura se najčešće koristi kod postojanja hroničnog bola. Ipak, više studija je pokazalo njenu delotvornost u terapiji akutnog bola. Do sada je poznto da se mehanizam dejstva akupunkture ogleda $\mathrm{u}$ istovremenoj aktivaciji nekoliko mehanizama za kontrolu bola u CNS-u. Tačka LI4 (Hegu) je jedna od najviše izučavanih tačaka u terapiji bola akupunkturom. Njena stimulacija je indikovana kod gotovo svih bolnih stanja, a delotvornost te stimulacije dobro dokazana. Algometrija je metoda koja se koristi za procenu bola i predstavlja pouzdanu i objektivnu metodu za procenu praga bola i njegove maksimalne tolerancije.

Cilj: Cilj rada bio je da se ispita da li se stimulacijom samo jedne akupunkturne tačke može postići značajan kratkotrajni analgetski efekat na mehaničke stimuluse, kao i da se utvrdi distribucija ovih efekata na telu (da li je samo lokalizovan, regionalni ili generalizovan).

Materijal i metode: Ispitivanu grupu činilo je 14 bezbolnih, zdravih studenta koji su prošli klinički pregled radi isključivanja postojanja bolnih stanja. Prag bola (PPDT) i maksimalna tolerancija bola (PPTT) su izmereni na 3 tačke na telu koristeći algometriju, pre i posle intervencije. Tokom intervencije, svi ispitanici su podvrgnuti akupunkturi na LI4 akupunkturnoj tački, bez manipulacije iglom, koja je ostala zabodena tokom 20 minuta.

Rezultati: Visoko statistički značajna promena je zabeležena kako za PPDT tako i za PPTT u sve 3 ispitane tačke nakon primene akupunkture u LI4 akupunkturnoj tački bez manipulacije iglom. Nisu zabeležene statistički značajne razlike između srednjih vrednosti promena $u$ PPDT i PPTT među tačkama.

Zaključak: Čak i stimulacija jedne akupunkturne tačke može dovesti do značajnog kratkotrajnog generalizovanog analgestkog efekta, koji je utvrđen korišćenjem mehaničkog stimulusa koji prouzrokuje eksperimentalni bol.

Klučne reči: akupunktura, analgezija, bol, LI4, LI10, algometrija, PPDT, PPTT, mehanički bol
Abstract

Introduction: In western countries, acupuncture as therapy for pain, is commonly used in treatment of the chronic pain. However, several studies have pointed out its success in treatment of acute pain. It is shown that acupuncture works through simultaneous activation of several pain control mechanisms in CNS. Acupuncture point LI4 (otherwise known as Hegu), is one of the most studied points in acupuncture treatment of pain. Its stimulation is indicated in almost all painful conditions, and its effectiveness is well proven. Algometry, used for pain assessment, has been widely recognized as reliable and objective method for measuring pressure pain threshold and tolerance.

Aim: The aim of this study was to explore whether a single acupuncture treatment shows significant shortterm analgesic effect on mechanical stimuli, and to determine the distribution of these effects across the body (whether localized, regional or generalized).

Material and Methods: Study group included 14 healthy, pain-free students who have passed clinical examination for any possible painful conditions. Pressure pain detection threshold (PPDT) and pressure pain tolerance threshold (PPTT) were measured on 3 points across the body using algometry, before and after interventions. For intervention, all subjects have received deep needling of LI4 acupuncture point, without needle manipulation, administered for duration of 20 minutes.

Results: Statistically significant rise in PPDT and PPTT has been observed in each of 3 measured points, following the needling of LI4 acupuncture point, without needle manipulation. There were no significant differences in mean change of PPDT and PPTT upon comparing changes between points.

Conclusion: Even a single manual acupuncture point stimulation, can have significant short-term generalized analgesic effect, which is determined using mechanical stimuli to cause experimental pain.

Key words: acupuncture, analgesia, pain, LI4, LI10, algometry, PPDT, PPTT, mechanical pain, pressure, threshold, tolerance 


\section{Introduction}

Pain is one of the main reasons for which patients seek help from physicians, as it can significantly interfere with a person's quality of life and general functioning [1]. Acupuncture as a therapy for pain, has been officially recognized and regulated by the most of the western countries [2]. Today, it is commonly used in treatment of chronic pain. However, several studies have pointed out success of acupuncture in treatment of acute pain [3-5]. Results of those studies indicate that most of the patients didn't need any additional analgesics (or it has led to great reduction in their application). But most of these studies have used multiple acupuncture point stimulation to produce analgesia.

Acupuncture as a part of the Chinese traditional medicine (CTM) has been used for over 2000 years in treatment of various pain conditions. According to the traditional acupuncture practice, body physiological functions are modulated by 12 bilaterally distributed channels (six Yin and six Yang), supplemented by two midline channels. Through them, circulates the hypothetical "Qi" Through inserting needles, and their appropriate manipulation, one can modulate the flow of Qi and relieve the pain [6-7].

Today the general agreement of scientific community is that acupuncture works though simultaneous activation of multiple pain control mechanisms. Some of main mechanisms involved are increase of endogenous opiates ( $\beta$-endorphin, encephalin, endomorphin), activation of descendenting pain inhibitory pathway and modulation of nociception in spinal cord through "Gate-control" mechanism [8-12].

LI4 (Large intestine 4) acupuncture point (otherwise known as $\mathrm{Hegu}$ ), is one of the most studied points in acupuncture treatment of pain. According to the principles of acupuncture, stimulation of LI4 is indicated in almost all painful conditions, and it's effectiveness in pain treatment has been analyzed in multiple clinical studies $[13,14]$.

However objective pain assessment is usually quite complicated, as pain is subjective and individual experience. Algometry has been widely recognized as reliable method for measuring pressure pain threshold and tolerance, using mechanical pressure as a numerical value for pain assessment, and has been described as a tool for pain assessment in several clinical cases and papers [15-17].

Aim of this study was to explore whether a single acupuncture treatment shows significant short-term analgesic effect on mechanical stimuli, and to determine the distribution of these effects across the body (whether localized or generalized).

\section{Material and methods}

This study was performed in Clinic for rehabilitation "Dr Miroslav Zotovic", Sokobanjska 13, Belgrade, at the department of Neurorehabilitation. The study was approved by the local ethics committee. Written informed consent was obtained from all participants.

\section{Participants}

14 healthy, pain free volunteers were chosen among students who have passed clinical examination. The mean age was $23.4 \pm 1.8$ years. Exclusion criteria were: any painful condition, current intake of analgesic drugs, antidepressants, anticonvulsants, neurological disorders, diabetes mellitus, vasculitis and pregnancy.

\section{Procedure}

Prior to intervention Pressure pain detection threshold (PPDT) and Pressure pain tolerance threshold (PPT) were measured on 3 points (Picture 1). They were chosen to determine whether the distribution of effects on PPDT and PPTT were localized, present in adjacent neural segment or were the effects generalized. The points for measurement were:

- LI4 on the right hand - point of needle insertion

- LI10 on the right hand - point adjacent to the site of needle insertion

- LI4 on the left hand - point for measurement of generalized effects

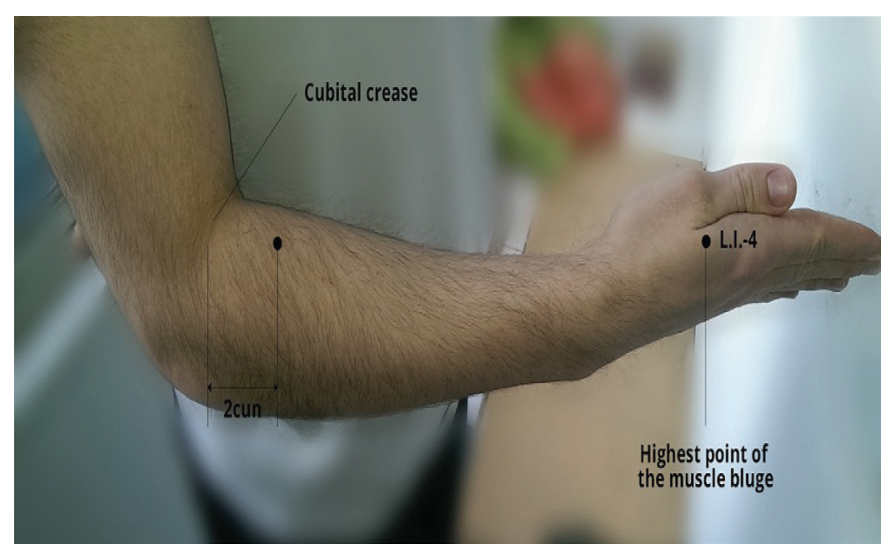

Picture 1. Location of LI4 and LI10 Acupuncture point on right hand

PPDT and PPTT were measured by applying mechanical pressure using electronic Algometry (Algometer Type II, Somedic AB, Horby, Sweden). This method represents a modification of method described by Fischer [15]. Pressure was applied using a $1 \mathrm{~cm}^{2}$ probe with 
constant increase of pressure at a rate of $30 \mathrm{kPa} / \mathrm{sec}$. Subjects were instructed that PPDT is the pressure that fist becomes uncomfortable or painful, and that they should signal as soon as this was perceived. PPTT was described as maximum tolerance to pain caused by increase of pressure, and upon reaching this feeling the measurement would stop.

The measurements were recorded 3 times, with 5 minutes breaks in between them, in order to get mean preintervention baseline. Upon completing this, participants were given 5 days of rest.

After that, all subjects have received deep needling of LI4 without needle manipulation, using sterile stainless steel disposable needle. It was inserted for duration of 20 minutes, at a depth of $15-20 \mathrm{~mm} .10$ minutes upon needle removal, PPDT and PPTT were assessed again using the same protocol that was used to determine baseline mean value in order to asses post intervention changes to PPDT and PPTT.

\section{Results}

Mean values changes on LI4 right hand are represented on the Figure 1. Mean values of PPDT have increased from $226 \pm 43 \mathrm{kPa}$ to $286 \pm 65 \mathrm{kPa}$ while values of PPTT have increased from $411 \pm 76 \mathrm{kPa}$ to $539 \pm$ $96 \mathrm{kPa}$ after application of manual needle acupuncture. There was a highly significant mean value increase for both PPDT and PPTT after application of acupuncture $(\mathrm{p}<0.001)$.

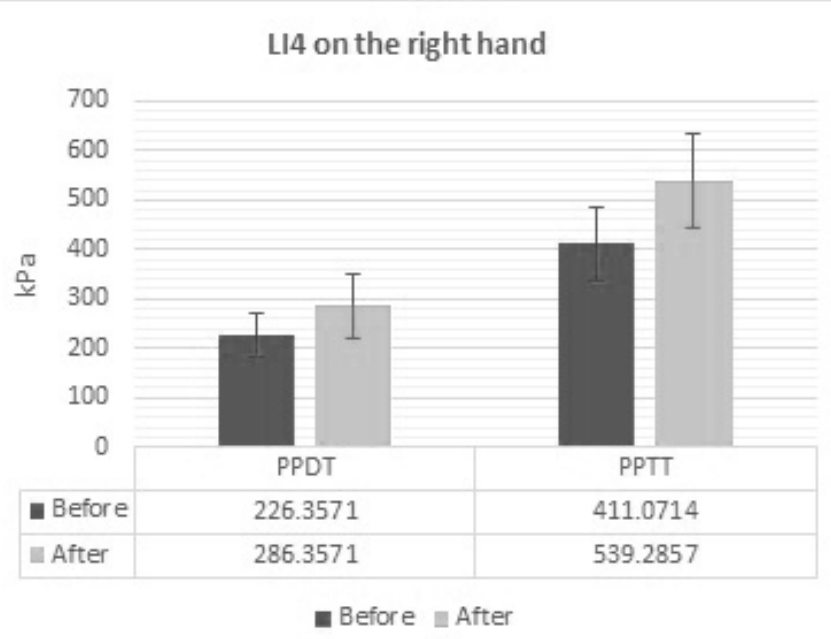

Figure 1. Mean values changes on LI4 - right hand

Mean values changes on LI10 right hand are given on the Figure 2. Mean values of PPDT have increased from $218 \pm 37 \mathrm{kPa}$ to $298 \pm 48 \mathrm{kPa}$ while values of PPTT have increased from $379 \pm 64 \mathrm{kPa}$ to $515 \pm 91 \mathrm{kPa}$ after application of manual needle acupuncture. There was a highly significant mean value increase for both PPDT and PPTT after application of acupuncture $(\mathrm{p}<0.001)$.

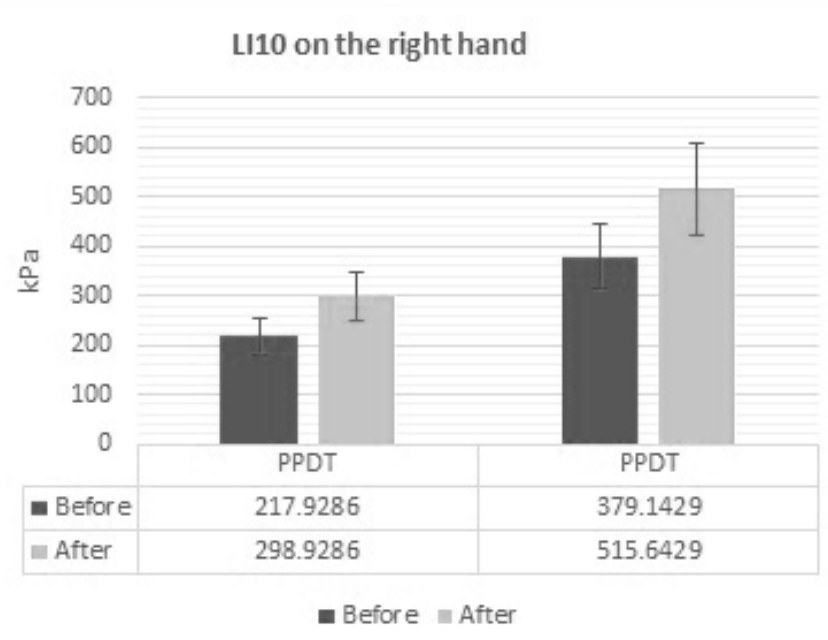

Figure 2. Mean values changes on LI10 - right

Mean values changes on LI4 left hand are represented on the Figure 3. Mean values of PPDT have increased from $238 \pm 32 \mathrm{kPa}$ to $314 \pm 63 \mathrm{kPa}$ while values of PPTT have increased from $401 \pm 67 \mathrm{kPa}$ to $527 \pm$ $93 \mathrm{kPa}$ after application of manual needle acupuncture. There was a highly significant mean value increase for both PPDT and PPTT after application of acupuncture $(\mathrm{p}<0.001)$.

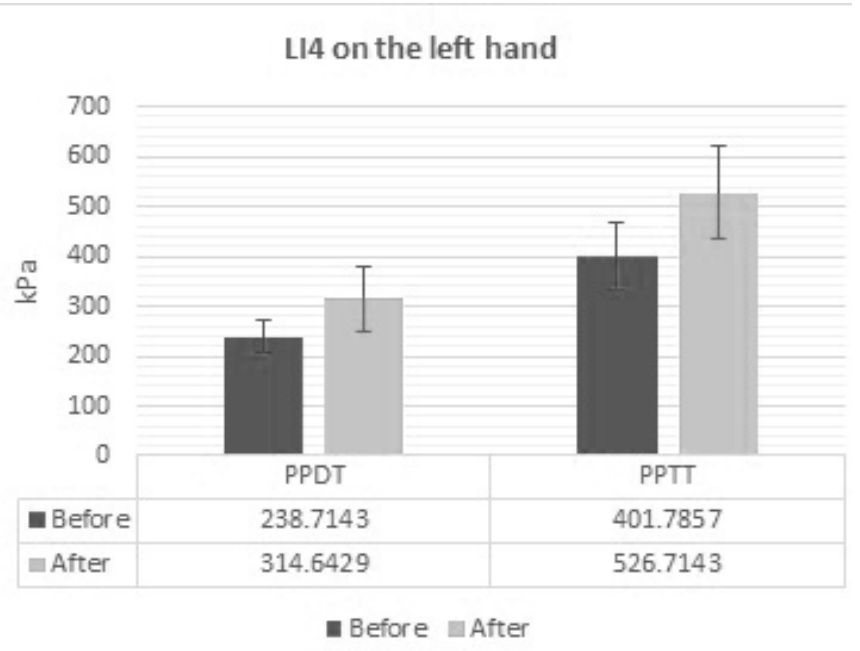

Figure 3. Mean values changes on LI4 - left hand

Aside from analyzing differences in PPDT and PPTT in each point, we have compared the mean differences between points LI4 right, LI10 right and LI4 left for both PPDT and PPTT.

Mean difference values of PPDT were: for LI4 right $60 \mathrm{kPa}$, for LI10 right $81 \mathrm{kPa}$, and for LI4 left $75 \mathrm{kpa}$. We have concluded that there is no significant difference between points $(\mathrm{p}=0.47)$. 
Mean difference values of PPTT were: for LI4 right $128 \mathrm{kPa}$, LI10 right $136 \mathrm{kPa}$, and for LI4 left $125 \mathrm{kpa}$. We have concluded that there is no significant difference between points $(\mathrm{p}=0.82)$.

\section{Discussion}

The results from our study indicate that analgesic effect of acupuncture on healthy individuals can already be demonstrated after a single treatment. This immediate effect can be observed in:

- LI4 on the right hand - Through significant rise of PPDT and PPTT (presented in Figure 1), upon acupuncture stimulation, we can notice a local analgesic effect, as that was the point of needle stimulation.

- LI10 on the right hand - As there was a significant change in PPDT and PPTT (presented in Figure 2) on this point as well, we can conclude that regional analgesic effect is also present.

- LI4 on the left hand - Observing the significant rise of PPDT and PPTT (presented in Figure 3) in that point, we can demonstrate generalized analgesic effect of single treatment.

This adds to existing knowledge by confirming the fast onset of acupuncture analgesia demonstrated in multiple studies $[18,19]$. Another study has found that acupuncture application of 25 minutes, has showed an acute analgesic effect that has lasted for at least 24 hours [20], however the agreement of scientific community stands that for prolonged effects, multiple, repeated sessions are needed.

Comparing our results to other studies which have used LI4 we can see that three studies have reported significant analgesic effect $[18,21,22]$, while three other studies have found no analgesic effect [23-25]. These contradictory findings of similar analysis could be contributed to possible differences in needle manipulation, size of studies or methodology.

What is interesting is that study done by Zaslawski et al. [22] has found generalized increase in all analyzed points (10 of them) after needling LI4 with needle manipulation (rotation of needle between the fingers in bidirectional manner), but has failed to observe significant generalized increase in PPDT following needling of LI4 without manipulation! This contradictory effect could be attributed to differences in choice of measurement points or possibly different times when PPDT was assessed upon acupuncture.

Analyzing mean differences between points we have determined that there is no significant difference in analgesic effect between local, regional and general changes in PPDT and PPTT, which further points to in- volvement of central mechanisms in acupuncture analgesia.

Generalized onset of acupuncture analgesia in our study could possibly be explained through involvement of central pain suppression mechanisms such as:

- Modulation of nociception through "Gate control" mechanism $[11,12]$ which could explain the immediate regional analgesic effect $[19,26,27]$, however it is insufficient to provide generalized effect.

- Increase of endogenous opioid substances. As most of the studies focusing on involvement of endogenous opioids have taken measurements shortly after application of acupuncture it is safe to assume that endogenous opioids could be one of main factors responsible for pain tolerance increase $[5,18,19,28,29]$.

- Descendenting pain inhibitory system where serotonin (5-HT) as main neurotransmitter plays a central role through involvement of nuclei raphe and periaqueductal grey mass. Through experimental animal studies the importance of descententing 5 -HT systems seems well supported [30,31].

- Endorphines and 5-HT play an important part in acupuncture analgesia, and these systems work in unison in creation of analgesic effect $[8,32]$. Therapeutic success of acupuncture in treatment of pain can certainly be ascribed to its simultaneous activation of several central pain control systems.

However limitations of our study can be prescribed to small number of subjects, lack of randomization and placebo control group. Randomization, and proper control group are methods of much debate in proper design of acupuncture studies. It is practically impossible to design double-blind trials as researcher has to know the acupuncture points which are stimulated [33]. Also any puncture of the skin increases the endorphin level of the cerebrospinal fluid, causing mild analgesia [9]. Therefore the reliability of typical controls used, such as sham or minimal puncturing acupuncture, remains questionable as reliable method for control [34].

Still even with these limitations, we believe that this is a step forward in recognition of acupuncture in treatment of painful conditions. Further studies are still needed, with proper control and larger number of patients with acute painful conditions, to evaluate potential therapeutic value of acupuncture in treatment of acute pain, which could potentially lead to improvement of pain treatment through combination with current methods.

Given all the results above, we can conclude that even a single manual acupuncture point stimulation can have significant short-term generalized analgesic effect which is determined using mechanical stimuli to cause experimental pain. 


\section{References}

1. Vadivelu N, Urman RD, Hines RL, Kunnumpurath S. Essentials of Pain Management. Springer-Verlag New York. 2011. p. 3-25.

2. Regulation of acupuncture from: en.wikipedia.org/wiki/ Regulation_of_acupuncture

3. Taguchi R. Acupuncture Anesthesia and Analgesia for Clinical Acute Pain in Japan. Evid Based Complement Alternat Med. 2008;5(2):153-8.

4. Wu S, Sapru A, Stewart MA, Milet MJ, Hudes M, Livermore LF. et al. Using acupuncture for acute pain in hospitalized children. Pediatr Crit Care Med. 2009 May;10(3):291-6.

5. Grillo CM, Wada RS, da Luz Rosário de Sousa M. Acupuncture in the Management of Acute Dental Pain. J Acupunct Meridian Stud. 2014 Apr;7(2):65-70.

6. Sahmeddini SA. Traditional Theory. In: Saad M, editor. Acupuncture - Concepts and Physiology. Rijeka: InTech; 2011. p. 3-24.

7. Han J. Acupuncture analgesia: Areas of consensus and controversy. Pain. 2011;152(3 Suppl):41-8.

8. Han JS et al. Dual control of acupuncture analgesia by central 5-hydroxytryptamine and morphine-like substances. Nat Med J China. 1978;58:721-25.

9. Han JS, Terenius L. Neurochemical basis of acupuncture analgesia. Ann Rev Pharmacol Toxicol 1982;22:193-220.

10. Lin JG, Chen WL. Acupuncture analgesia: a review of its mechanisms of actions. Am J Chin Med. 2008;36(4):63545.

11. Melzack R. From the gate to the neuromatrix. Pain. 1999; Suppl 6:121-6.

12. Melzack R, Wall PD. Pain mechanisms: a new theory. Science. 1965;150(3699):971-9.

13. Lang T, Hager H, Funovits V, Barker R, Steinlechner B, Hoerauf K, et al. Prehospital analgesia with acupressure at the Baihui and Hegu points in patients with radial fractures: a prospective, randomized, double-blind trial. Am J Emerg Med. 2007;25(8):887-93.

14. Dabiri F, Shahi A. The Effect of LI4 Acupressure on Labor Pain Intensity and Duration of Labor: A Randomized Controlled Trial. Oman Med J. 2014;29(6):425-9.

15. Fischer AA. Pressure algometry over normal muscles. Standard values, validity and reproducibility of pressure threshold. Pain. 1987;30(1):115-26.

16. Ohrbach R, Gale EN. Pressure pain thresholds in normal muscles: reliability, measurement effects, and topographic differences. Pain. 1989;37(3):257-63.

17. Treede RD, Rolke R, Andrews K, Magerl W. Pain elicited by blunt pressure: neurobiological basis and clinical relevance. Pain. 2002 Aug;98(3):235-40.

18. Schliessbach J, van der Klift E, Arendt-Nielsen L, Curatolo $\mathrm{M}$, Streitberger K. The effect of brief electrical and manual acupuncture stimulation on mechanical experimental pain. Pain Med. 2011;12(2):268-75.

19. Molsberger A, Hille E. The analgesic effect of acupuncture in chronic tennis elbow pain. $\mathrm{Br} \mathrm{J}$ Rheumatol. 1994;33(12):1162-5.
20. Zheng Z, Feng Sj, Costa Cd, Li CG, Lu D, Xue CC. Acupuncture analgesia for temporal summation of experimental pain: a randomised controlled study. Eur J Pain. 2010;14(7):725-31

21. Stacher G, Wancura I, Bauer P, Lahoda R, Schulze D. Effect of acupuncture of pain threshold and pain tolerance determined by electrical stimulation of the skin: a controlled study. Am J Chin Med (Gard City N Y). 1975;3(2):143-9

22. Zaslawski CJ, Cobbin D, Lidums E, Petocz P. The impact of site specificity and needle manipulation on changes to pain pressure threshold following manual acupuncture: a controlled study. Complement Ther Med. 2003;11(1):11-21.

23. Li CL, Ahlberg D, Lansdell H, Gravitz MA, Chen TC, Ting $\mathrm{CY}$, et al. Acupuncture and hypnosis: effects on induced pain. Exp neurol. 1975; 49(1 Pt 1):272-280.

24. Lundeberg T, Eriksson S, Lundeberg S, Thomas M. Acupuncture and sensory thresholds. Am J Chin Med. 1989;17(3-4):99-110.

25. Micalos PS, Pak SC. Noneffect of Manual Needle Acupuncture on Experimental Pain Parameters in Healthy Young Men. J Altern Complement Med. 2011 Jan;17(1):57-61.

26. Inoue M, Kitakoji H, Ishizaki N, Tawa M, Yano T, Katsumi Y, et al. Relief of low back pain immediately after acupuncture treatment-a randomised, placebo controlled trial. Acupunct Med. 2006;24(3):103-8.

27. Irnich D, Behrens N, Gleditsch JM, Stör W, Schreiber MA, Schöps P, et al. Immediate effects of dry needling and acupuncture at distant points in chronic neck pain: results of a randomized, double-blind, sham-controlled crossover trial. Pain. 2002;99(1-2):83-9.

28. Mayer DJ, Price DD, Rafii A. Antagonism of acupuncture analgesia in man by the narcotic antagonist naloxone. Brain Res. 1977;121(2):368-72.

29. He LF. Involvement of endogenous opioid peptides in acupuncture analgesia. Pain. 1987;31(1):99-121.

30. Research Group of Acupuncture Anesthesia, Peking Medical College. 1975. The effects of parachlorophenylalanine on acupuncture analgesia in the rabbit. Kexue Tongboa 20:483-85.

31. Research Group of Biochemistry, Institute of Acupuncture and Moxibustion, Academy of Traditional Chinese Medicine. 1980. The relationship between acupuncture analgesia and the monoamine transmitters in rat brain. In Advances in Acupuncture and Acupuncture Anesthesia, pp. 425-26. Beijing: People's Med. Pub!. House. 541 pp.

32. Han JS, et al.. Central 5-hydroxytryptamine, opiate-like substances and acupuncture analgesia. Research on acupuncture,moxibustion and acupuncture anesthesia, Beijing. 1986:309-16.

33. Vincent CA, Richardson PH. The evaluation of therapeutic acupuncture: concepts and methods. Pain. 1986;24(1):113.

34. Lund I, Lundeberg T. Are minimal, superficial or sham acupuncture procedures acceptable as inert placebo controls? Acupunct Med. 2006;24(1):13-5. 